\title{
THE CONCEPT OF AUTHORIZATION (BEZIT) IN SALES AND PURCHASE TRANSACTIONS OF VIRTUAL PROPERTY
}

\author{
Lintang Yudhantaka ${ }^{1}$; Ninis Nugraheni ${ }^{2}$ \\ ${ }^{1}$ Faculty of Law, Airlangga University, Surabaya \\ ${ }^{2}$ Faculty of Law, Hang Tuah University, Surabaya \\ E-mail: lintang.yudhantaka@gmail.com
}

\begin{abstract}
Virtual property such as softwares, e-books, and games are commonly seen as things with economic values. The existence of virtual property itself does not only exist in the virtual world or cyberspace, but virtual property is also treated as an object in general. The existence of these virtual property also has the potential to cause problems in the future, especially regarding proprietary rights, due to the absence of regulations governing virtual property. This study discusses the position of bezitter in the authorization of virtual property and the object delivery in sales and purchase transactions of virtual property. Juridical-normative method with statute and conceptual approaches are all applied. The result shows that bezitter is seen as the owner, and thus, a sales-and-purchase transaction as well as the object delivery of virtual property is considered valid and enforceable if it is in accordance to what it has been agreed in End User License Agreement (EULA). The government should make regulations regarding virtual property immediately in order to minimize problems that arise in the future.
\end{abstract}

Keywords: authorization (bezit), sales and purchase, virtual property

\section{A. INTRODUCTION}

Human society over the world is never apart from things called goods. Goods are always available in every transaction by individuals on their daily and social life. Hence, it makes goods necessary to be arranged. In Indonesia, such thing is set in Book II Burgerlijke Wetboek (later called BW). Based on Article 499 BW, goods are any things and rights that an individual may possess (proprietary right) (Kansil, 1995:157). The most extensive definition of the term "goods" (Zaak) is any thing that may belong to an individual. Such definition poses goods into an object as opposed by subject or individual in the context of law. In narrower setting, goods are defined as those tangible only (Subekti, 2005:60). Some rights adhere to a good, such as proprietary, bezit, and civil rights over others' proprietary right (Nurhayani, 2015:192).

Yustisia Volume 8 Number 1 (January-April 2019)

The Concept Of Authorization 
The right of goods (zakelijk recht) is absolute rights to an object that gives a direct dominance to an individual on a good wherever it is (Usanti, Lahirnya Hak Kebendaan, Perspektif, Volume XVII, No. 1, Januari 2012: 45). In other words, the law of goods is every legal norm that regulates goods and/or anything related to it. In this case, goods in everything in respect of the definition of goods, the discernment of goods, and proprietary rights and others related to goods and proprietary rights (Usman, 2011:34).

The law of goods is set in Book II BW with dwingenrecht characteristic (i.e., compelling/reclusive). As the result, it has a reclusive system that individuals may not organize the rights of goods (Zakelijk Recht) but as regulated under Book II $\mathrm{BW}$, another regulation or jurisprudence. Therefore, people may only organize the rights of goods as mentioned in that regulation. That is, the number of such rights is limitative on what is mentioned in regulation or at least jurisprudence (Usman, 2011:38). As the time goes by, however, the development of technology makes the function and existence of goods has shifted from conventional to digital or virtual. Such goods are known as virtual property.

No definition is set by Indonesia legislation on virtual property. Nevertheless, some experts on virtual property have proposed their thoughts as reference. Michael Meehan, for instance, defined virtual property as "those which are created within a virtual world and which do not have an external existence outside of that environment" (Meehan, Virtual Property: Protecting Bits in Context, 13 Rich JL \& Tech, Volume XIII, Issue 2, 2006: 7). For him, virtual property is made in a virtual world and has no existence out of its virtual field (Wayne, Theft In The Digital: Can You Steal Virtual Property?, Canterbury Law Review, Volume 17, Issue 2, 2011: 361).

Peter Brown \& Richard Raysman (Brown \& Raysman, Property Right in Cyberspace Games and Other Novel Legal Issues in Virtual Property, The Indian Journal of Law and Technology, Vol.2, 2006: 89) argues that virtual property is individual's assets or things that individual may possess and the ownership of those things is valuable. Such valuability refers to economic value that can be exchanged by real money through sales and purchase transactions or the agreement of exchange between virtual objects. Again, virtual property is only in virtual world called cyber world.

Joshua A. T. Fairfield (Fairfield, Virtual Property, Boston University Law Review, Vol. 85, 2005: 1048) also emphasizes that virtual property is a code using a computerized system and spread out through internet in such a way and its treatments is simiar to the property in real world.

Recently, a phenomenon of virtual property causes new things to occur, especially in Indonesia legislation. The term virtual itself refers to intangible, and therefore, virtual property is simply defined as intangible property with no physically tangible form. It raises a question of what is virtual property? And How is the position? In 
addition, any activities associated to such virtual property may carry out a novel legal indication such as the definition of rights to virtual property in sales and purchase transactions, for instance.

Buying and selling virtual property has been popular in communities through digital platforms such as google play and steam using smartphones or computer with internet access. Merchandising through internet access is no longer new for current people. Internet is the most fundamental technology since the discovery and revolution of personal computer, as it is a more interesting way to use websites as a common base for more extensive business application. As the technology of internet and website develop, these technologies improve both individuals' and organizations' capability and sophistication on business communiation in terms of sharing various information and other valuable and scarce sources (Nugroho, 2006:2-3).

The development of global technology for these couple years makes some technologies such as games, books, softwares, and film which previously came out with conventional form (i.e., softwares and films were available in compact disk/CD, and books in paper based) and now has shifted to digital or virtual form and been sold by various digital platforms such as google play and steam. The payment method that google play and steam commonly $u$ ses is through credit card or vouchers called google gift and wallet gift, respectively. Each of those cards has such a serial number for logging into google play and steam in the form of virtual money which can be used for having transactions on virtual properties those platforms sell.

The existence of virtual properties may potentially cause problems in the future. Therefore, Indonesia legal system should be capable to respond to those problems, given that virtual object is new in people life. One case of intellectual asset in cyber world which is not settled yet is virtual property rights. This case happened in China (2005) and United States (2007). It often happens in online-games and eventually turns into a seizure of property rights.

As reported by mass media in China on June 2005, an individual named Qiu Chengwei (41 yo) reported his friend to China police force. His friend is suspected having a legal violation as he had sold his game items he had lend without his permission. However, the police force refused the report with a pretext that the virtual property was not recognized by the legal system of China, and thus, it might not be sued (Whitworth, 2014: 13). Everything starts from Chengwei who had recently acquired a powerful weapon (called Dragon Sabre) and lent it to Caoyuan (his friend), who then sold it on eBay for 7200 yuan. Zhu Caoyuan had initially promised to return the virtual sword. After selling it, he promised Chengwei the money he received for it. But unfortunately, promising the money was not sufficient to assuage Chengwei. With no help from the police - Caoyuan had broken no law - and no compensation from Caoyuan, Chengwei attacked and murdered his former friend (Madary, Intentionality 
and Virtual Objects: The Case of Qiu Chengwei's Dragon Sabre, Springer: Ethics and Information Technology, Volume 16, Issue 3, 2014: 219).

A similar case happened in United States, particularly related to www.secondlife. com. A gamer named David Denton bought an island in Secondlife at the price of USD 700 with real money. Denton sued Linden Lab as it secretly changed the online sales contract without his permission as the owner. Linden Lab tried to sell the game property to other people. As the consequence, it predicted that Linden Lab had injured 50.000 gamers with the amount of loss at USD 100.000.000. Linden Lab was sued violating the law of consumer protection and deception (Lazarus, "A Real-World Battle Over Virtual-Property Rights", available at https://www.latimes. com/archives/la-xpm-2010-apr-30-la-fi-lazarus-20100430-story.html, accesed on 15 February 2019).

From the two examples of these cases, it can be seen a phenomenon that the lack of legal protection against the status of a buyer of a virtual property which results in the loss of the buyer. Can a person who buys a virtual property be said to be fully an owner or just master but not fully be regarded as the owner? If so, then what is the right form of transition so that someone in the sale and purchase of virtual objects can be said to be the owner?

Based on the description, the authors are interested to analyze vitual properties, in particular to the position of bezitter in possessing virtual objects and the object delivery in sales and purchase transactions of virtual properties.

\section{B. PROBLEM STATEMENT}

The research problem of this study points to the position of Bezitter in the authorization of virtual properties, and the object delivery in sales and purchase transaction of virtual properties.

\section{RESEARCH METHOD}

A study of normative law is used, considering the exclusive character of the study itself which method is normative. This method is useful to analyze the correlation of legal regulations, jusprudence, and contracts. Doctrinal study, however, is used to analyze the principle of law, the literature of law, along with scholars' views of law that have high qualification (doctrine) and comparison of law.

As this study is a normative research, statute and conceptual approaches are applied. Statute approach is applied by examining the legislation and other related legal regulations on intended legal issue. It is an approach using legislation and regulation. In addition, conceptual approach is applied by using the perspectives and concepts from some experts to analyze the data collected, along with any growing

82 Yustisia Volume 8 Number 1 (January-April 2019) $\quad$ The Concept Of Authorization ... 
doctrines in the discipline of law as the basis of this study in order to construct the argumentation of law to solve the studied legal issue (Marzuki, 2009: 93).

\section{DISCUSSION AND RESEARCH RESULT}

\section{The Position of Bezitter in the Authorization of Virtual Property}

The provision of bezit in Article $529 \mathrm{BW}$ mentions that "bezit is a condition of controlling or enjoying an object an individual personally has authority on it or through other people, as if it were his/her own." Based on that article, bezit is a condition on which an individual has an authority of an object, either individually or through other people help as if it were his/her belonging (Muhammad, 2014: 161). However, Prof. Subekti defines bezit as an extrinsic condition that an individual possesses an object as if it were his/her belonging, and protected by law without questioning the actual proprietary right of that object (Hasbullah \& Syarif, 2000). Meanwhile, Sri Soedewi Masjchoen Sofwan (Sofwan, 1974) refers bezit to article $529 \mathrm{BW}$ of Civil Code that it is a condition of controlling or enjoying an object he/she posseses, either individually or through other people help as if it were his/her belonging.

From those several definitions, it was found that bezit provides a condition to an individual to posses an object, either directly or indirectly through other people assistance as if it were his/her belonging, and thus, those possessing an object have an authority to hold or enjoy the object he/she has control on it. Toward an object with unknown owner, an individual with authorization on that object can be assumed as the owner of the object. To be on such position, an individual should act as if he/she were the owner of the object (Usman, 2011: 141).

The party organizing bezit is a legal subject in which actually has an authority right as a concrete power on the object and thus making him/her own the object. The term "bezit" derives from zitten that refers to "positioning." It should have 2 elements on bezit, including the authorization on a particular object and a tendency to own the object. Bezit is different from detentie, a condition in which an individual posseses a particular object due to particular legal relationship with other people owning the object. In a lease relationship, for instance, a tenant of a house has an authority on the house he/she rents; however, the tenant is not considered having a tendency to own the house.

On bezit, an individual with dominance on particular object is not certainly the owner of the property. On people perspective, he/she is assumed as the owner as he/she physically seems controlling the object as if he/she were the owner without considering whether the authorization corresponds to the juridical condition. 
Naturally, an individual controlling a property is seen as the owner of the object he/she has control on it. The authorization may be individual or through other people assistance. In bezits, it does not question the actual owner of a property. That is, anyone controlling an object is considered as the owner of the object. The bezit-ation on an object by an individual may bring out what is called bezitter; one that bezits a property.

Rahmadi Usman argues that following Article 538 BW, bezit of a property occurs by (Usman, 2011:152-153):

a. "Collecting or positioning". That is, the presence of an active action by one self or through other people assistance for and on behalf;

b. What is positioned is "a property which may include moving and still objects. The moving object may include both those with and without owners.;

c. The collected property should be "on the authorization" of bezitter. It should show a direct relationship between one possessing an object and the object possesed;

d. There is a tendency to "posses or keep it for self", showing an animosity; a willing to posses the object for self.

In relation to the authorization of virtual property, an individual having a sales-and-purchase transaction of a virtual object is considered as the owner of the object. The authorization of application users on virtual properties is absolute. That is, they may keep their authorization on a virtual property from other people. Such authorization, however, is only on the content of utility on the virtual object. Virtual properties provided by the providers of an application (i.e., application developer) is merchandised for their application users and to support the attributes of an application.

Sales-and-purchase transaction is a process through which the delivery of a proprietary right occurs from the seller to the buyer. As mentioned in Article 1457 $\mathrm{BW}$, buying-and selling is an agreement through which a party engage him/herself to transfer a property, and another party pay for the property as agreed. Hence, it infers that the essential element of sales-and-purchase transaction is object and price. In relation to rights and obligation, furthermore, sellers must provide the merchandise and have right to get payment for it. In the part of buyers, they must pay for the merchandise and have right to get the merchandise. Therefore, it is clear that sales-and-purchase transaction is a part of a legal system with several elements as follow (Muhammad, 2014:319).

1. Legal subject

It refers to the seller and the buyer 
2. Legal status

It refers to personal or others' interests

3. Legal incident

It refers to the agreement of delivering a proprietary right along with the payment.

4. Legal object

It refers to the property and price

5. Legal relationship

It refers to the association between rights and obligations of the parties having an agreement.

In particular to virtual properties, the sales transaction is not apart from those related to virtual world (i.e., electronic transaction). Following article 1 subsection (2) of Act No. 19/2016 about Infromation and Electronic Transaction (later called UU ITE), electronic transaction is a legal action using computer, computer network, and/or any other electronic media.

Shinta Dewi classifies electronic transaction into two categories as follow (Dewi, 2009:54).

a. First, transaction using indirect electronic assistance in which the legal relationship between the seller and the buyer is made through internet, and the delivery of the property is conducted conventionally.

b. Second, transaction through direct electronic assistance. The legal relationship is conducted through internet, both the establishmen of agreement and the delivery of the property. In this case, the delivery is real time in which the property is automatically put on the account just after the buyer paied the merchandise, such as softwares, films, music, or download-able information.

In the context of buying and selling virtual property, the buyers may become the owner of the virtual property they have bought. However, the object may not be fully used as they want, given its specific characteristics different from conventional ones. In online games, for instance, although it is identified as a virtual object, we may not fully operate it without internet access to its center. In addition, the ownership of virtual property commonly refers to End User License Agreement (EULA) or a normative agreement initially provided by the provider of telecommunication services.

One example of EULA or a normative agreement about a proprietary right of virtual object is seen on online ragnarog game as follow (Ragnarok, "Ragnarok Private Server Indonesia", available at https://www.indoragnarok.com/tos/, accesed on 15 February 2019) : 
1) Users that agree EULA should comply with all the terms and condition of EULA. The condition is also applied to all game services provided by Ragnarok Private Server through its website (www.indoragnarok.com)

2) The users should do registration to use the services of Ragnarok Private Server. They should inform their ID correctly and completely. They are responsible to all the data they have registered. The Ragnarok Private Server has no responsibility on any default or errors during the registration.

3) All information and personal data the users register to Ragnarok Private Server is confidential, and the server will never give the information to other parties but the business partner in order to provide services to the users.

4) The users should be fully responsible to protect their ID, password, and any personal codes. They are also responsible to the activities they do with the ID.

5) All the characters, items, and elements of the game provided by Ragnarok Private Server belong to the developer. In case that the service of game is close, all those items be returned to the developer.

6) Ragnarok Private Service has an authority to refuse or delete the ID name, characters, or guild name on which they violate the law, offend particular tribe, religion, race, containing pornography, or against the norms applied in the Republic of Indonesia.

7) The users are not allowed to use the website, forum, and services of Ragnarok Private Server for promotional or commersial purposes.

8) Ragnarok Private Server has right to change or delete all the content of the website, forum, and any messages in its game application on which the server find any violation against the terms and condition, law, and social norms which may threaten or injure others' rights as follow.

- Messages that lead to violence, hatred, physical theat, drugs, abusement, humiliation, and those that offend particular tribes, religions, and races, as well as violating the applied norms.

- Messages about the procedures, instructions, or methods to violate the law, containing terrorism, hacking, cracking, etc.

- Messages containing commercial, promotional and advertorial purposes.

- Inappropriate messages.

9) The users are obligated to comply with all the terms and condition by Ragnarok Private Server. The server has right to give sanction or even blocking the ID of the users that break the terms.

10) Ragnarok Private Server will never be responsible to any loss due to the users' action, behavior, and messages in game application, as well as the messages they send to the website/forum. 
11) Ragnarok Private Server has right to close the services of online game anytime with a notification one month before.

12) Ragnarok Private Server has right to change the terms and End User License Agreement, Terms of Service, the regulation of the available game in order to improve the service quality without giving any notification before.

13) Online Ragnarok is a product of Gravity.Inc. Ragnarok Private Server is neither an official server nor official affiliation nor official partner of Gravity, Inc.

At point 6, the developer provides EULA in terms of the limitation of proprietary right which may not be fully owned by the buyers/users of online game. It is related to an exoneration clause. This clause refers to agreements along with the terms and conditions on the authority of one party (i.e., producers) about the obligation or responsibility shift of the product which, as the result, may injure the consumers (Hernoko, 2000: 65). Given the exoneration clause, the developer has an implicit tendency to shift his/her obligation. In case a virtual property has been bought by an individual, it should fully belong to the buyer.

Furthermore, what we should take into account is things related to the terms of EULA. The agreement is considered legal when it meets the term and condition of the agreement. In relation to the content of the agreement, the contracting parties are free to establish the content as long as it is not against the propriety, moralty, and applied norms (vide, Article 1320 BW, Article 1338 BW, Article $1337 \mathrm{BW})$. Hence, in case the buyers have agreed the EULA, although containing an exoneration clause, the EULA remains engaging the contracting parties.

\section{Object Delivery in Sales-and-purchase Transaction of Virtual Property}

The theory of right delivery defines that it should be a guideline that the delivery of a proprietary right on either moving or fixed object should be conducted by the actual owner of the object or by individuals with authority on the object. In case that such guideline is ignored, the ownership of the object may be flawed. Hence, it is possible that an individual possessing the object has no right to deliver or alienate the object. When it does not so, the delivery of the proprietary right is considered invalid, indicating that the object should be back to the actual owner (Mustofa, 1985: 42). Mr. Paul Scholten proposed this theory as "Legitimate Theorie" that "Generally, the proprietary right of an object may only be legally shifted if an individual get it from another individual authorized to transfer the right; the owner."

However, if we only rely on Scholten's theory, it may cause a concern or question in people mind that intend to get the object from the owner. In sales 
transaction of radio, for instance, the buyer may think whether the seller has right to sell the radio he/she buy. In case that the seller has no right on it, the transaction is considered invalid. Given the legal indication, it may obstruct the implementation of law. Therefore, Scholten's theory is refined in article 1977 BW. This article contains that the principle of authorization (bezit) is applied as the perfect basis of rights as follow. Toward the object but interest and account receivable which the carrier has no obligation to pay the account, whomever controlling the object is considered as the owner. With this article, every buyer does not need to worry that the buying and selling transaction they conduct is invalid in case that the owner is not the actual owner of the object since this article protect them (Mustofa, 1985: 43).

Another theory related to such delivery is eigendoms theories. This theory is proposed by Mejers who interpreted article $1977 \mathrm{BW}$ in grammatical manner. For Mejers, an individual honestly owning a moving object is the owner of the object without considering whether there is a valid basis for such right, whether it is from an individual owning the object or not. This theory puts aside the article 584 BW about the valid condition of a levering: it should have a valid base and should be conducted by an authorized party that posseses the object. The problem is which article that should follow between those two articles. Mejers argues that we should follow the article 1977 BW and ignore the terms of levering, and thus, Mejers' theory is no longer applied recently.

Every levering a proprietary right for either moving or immovable object, it is through two stages. First, there is an obligatoir agreement which aims to deliver a proprietary right. Second, there is a delivery of the agreement that deals with the delivery of the right itself. In case of delivering the proprietary right of moving objects, those two agreements are organized simultaneously. That is, after complying with all the terms contained in an obligatoir agreement, the delivery is then immediately conducted since the delivery of such object is conducted hands on hands.

As previously discussed, buying and selling transactions of virtual properties are not apart from the terms of buying and selling in general. There is always a delivery of proprietary right in the process of sales transactions. In case of virtual property, however, may not be fully owned, given that such object has specific characteristics. In the context of online game, for instance, when the developer decides to close the service of its application which may make all the items of the online game are all returned to the developer, the buyers may not sue the developer as agreed in the agreement. However, if the recollection of virtual property by the developer is based on terms out of what has been agreed in EULA, the buyers are allowed to have any particular legal action to get their 
rights back by filing a lawsuit of default. Such lawsuit is filed on which the developer has broken the agreement in EULA.

One feature of online game is the likelihood of buying and selling a virtual property, and the transaction may occur in and out of online setting by using real money. Buying and selling virtual property using real money in real world often raises problems since it occurs among the users and the providers of online game service may see this as an illegal action. Virtual properties commonly traded include virtual items, accounts, and currency.

The reason behing such ban by the provider of online game service is because it may disturb the system of economy in their game application, which seems unfair for the users (Landy, 2008:630). The users with much money may easily buy any virtual properties they want. Otherwise, those with limited money must take a lot of efforts to get a virtual property, and thus, they should be wiling to spend much time for the sake of virtual property they want. Therefore, such buying and selling transaction is considered illegal and banned according to the provision in EULA of Term of Service.

Some online games firmly assert using a clause in EULA of Term of Service that they ban any sales transaction of virtual property using real money. The example can be seen in Terms of Service of Dragon Nest SEA, as follow (DragonNest, "Policy", available at https://sea.dragonnest.com/policy/operationpolicy, accesed on 15 February 2019).

\section{Account and Item Trading}

EYEDENTITY Games does not endorse selling or trading of accounts. All game characters and items are owned by EYEDENTITY Games. Players engaged in such activities responsible for any risk involved. All emails to Game Masters concerning Account and Item Trading will be disregarded.

\begin{tabular}{|c|c|c|c|}
\hline \multirow{2}{*}{ Ref No. } & \multirow{2}{*}{ Violation } & \multicolumn{2}{|c|}{ Offense } \\
\hline & & $1^{\text {st }}$ & $2^{\text {nd }}$ \\
\hline DN-TRD-01 & $\begin{array}{l}\text { Intention and/or Action to } \\
\text { trade gold for real cash and } \\
\text { vice-versa without an in- } \\
\text { game commodity. Examples: } \\
\text { selling gold for real cash. }\end{array}$ & $\begin{array}{l}\text { Fourteen (14) } \\
\text { days Game } \\
\text { Account Ban } \\
\text { Mandatory } \\
\text { Inventory }\end{array}$ & $\begin{array}{l}\text { Permanent } \\
\text { Game } \\
\text { Account } \\
\text { Ban }\end{array}$ \\
\hline DN-TRD-02 & $\begin{array}{l}\text { Intention to conduct illegal } \\
\text { buying, selling or trading of } \\
\text { account/s. }\end{array}$ & $\begin{array}{l}\text { Wipe for all } \\
\text { characters. }\end{array}$ & \\
\hline
\end{tabular}




\begin{tabular}{|clc|}
\hline Ref No. & \multicolumn{1}{c|}{ Violation } & Offense \\
\hline DN-TRD-03 & $\begin{array}{l}\text { Offering monetary services to } \\
\text { babysit, power level, or pilot } \\
\text { game character/s that requires } \\
\text { direct access to the recipient's } \\
\text { account/s. }\end{array}$ & \\
\hline
\end{tabular}

Based on the terms of service, it is found that the clause in Terms of Service of Dragon Nest SEA firmly ban any sales-and-purchase transaction of some of their virtual properties that seems illegal, including the sales transaction of virtual properties among users by using real money. For every sales transacton that seems illegal, it will be charged with severe sanction such as permanently banned on the users' account.

Therefore, such sales-and-purchase transaction may not be considered as enforceable when it deals with the providers of the online game service, since the users have agreed the EULA or Terms of Service before playing the game. In accordance to article $1338 \mathrm{BW}$, it mentions that every agreement legally organized is applied as regulation for those creating the agreement, and thus, the clause in EULA or Terms of Service engages both parties; the developer and the users of the online game service. The users may likely have a sales transaction of a virtual property to one another with a consequence that it is not enforceable to the developer of the online game service. If, someday, the developer finds such transaction among their users and directly gives charge on them as the sanction, the users may not sue the developer of the online game service (Purwanta, 2012: 165).

\section{E. CLOSING}

An Individual having a buying and selling transaction of a virtual property has right on the object. The authorization by bezitter (i.e., the user of an application) on the virtual property is absolute. That is, one may hold the authorization of a virtual object from others. If the transaction occurs, the position of bezitter is as the owner of the object. As the consequence, based on article $1457 \mathrm{BW}$, there will be a shift of proprietary right from the seller to the buyer.

In relation to the delivery of a virtual property in the process of buying and selling transaction, it is similar to those in conventional setting. The buyers may do the payment through any digital platforms such as google play and steam using credit card or voucher called google gift for google play and wallet gift for steam. The buyers may get the virtual property in related application after making the payment.

$90 \quad$ Yustisia Volume 8 Number 1 (January-April 2019) $\quad$ The Concept Of Authorization ... 
To avoid any confusion in the future regarding virtual property, the Indonesian government needs to make a special regulation about virtual property. The regulation contains at least the ownership of virtual property and how to transfer it rights. Thus, it is expected to provide clarity and minimize the conflicts of interest between developers (application builder) and buyers (application users) in the future.

\section{BIBLIOGRAPHY}

\section{Books:}

Dewi, Shinta, 2009, Perlindungan Privasi Atas Informasi Pribadi Dalam Ecommerce Menurut Hukum International (Privacy Protection for Personal Information in E-Commerce According to International Law), Widya Padjajaran: Bandung.

Hasbullah, Frieda Husni dan Surini Ahlan Syarif, 2000, Materi Perkuliahan Hukum Perdata Buku A (Lecture Materials in Civil Law, Book A), Fakultas Hukum Universitas Indonesia: Depok.

Hernoko, Agus Yudha, Sarwini dan Budi Kagramanto, 2000, Kebebasan Berkontrak Dalam Kontrak Standard (Freedom of Contract in a Standard Contract), Editor Puspa Ragam Informasi dan Problematika Hukum, Karya Abditama: Surabaya.

Kansil, C. S. T., 1995, Modul Hukum (Law Module), Pradnya, Paramita: Jakarta.

Landy, Gene K., 2008, The IT/Digital Companion a Comprehensive Business Guide to Software, Internet, and IP Law Includes Contract and Web Forms, (United States: Syngress publishing).

Marzuki, Peter Mahmud, 2009, Penelitian Hukum (Legal Research), Kencana Prenada Media Group: Jakarta.

Muhammad, Abdulkadir, 2014, Hukum Perdata Indonesia (Indonesia Civil Law), PT. Citra Aditya Bakti: Bandung.

Mustofa, Bachsan, Bevva Ragawino dan Yaya Priatna, 1985, Asas-Asas Hukum Perdata dan Hukum Dagang (Principles of Civil and Commercial Law), Penerbit Armico Bandung: Bandung.

Nugroho, Adi, 2006, e-Commerce, Informatika: Bandung.

Nurhayani, Neng Yani, 2015, Hukum Perdata (Civil Law), Pustaka Setia: Bandung.

Purwanta, Mahendra Adhi, 2012, Analisa Hukum Terhadap Transaksi atas Kebendaan Virtual pada Penyelenggaraan Permainan Online (Legal Analysis of Transactions on Virtual Material in the Implementation of Online Games, Tesis, Fakultas Hukum Universitas Indonesia.

Sofwan, Sri Soedewi Masjhoen, 1974, Hukum Perdata: Hukum Benda cetakan keempat (Civil Law: The fourth law of The Printed Matter), Liberty: Yogyakarta. 
Subekti, 2005, Pokok - Pokok Hukum Perdata (Principles of The Civil Law), Intermasa: Jakarta.

Usman, Rachmadi, 2011, Hukum Kebendaan (Property Law), Sinar Grafika: Jakarta.

\section{$\underline{\text { Journals: }}$}

Brown, Peter, \& Richard Raysman., 2006, "Property Right in Cyberspace Games and Other Novel Legal Issues in Virtual Property", The Indian Journal of Law and Technology, Volume 2.

Fairfield, Joshua A. T., 2005, "Virtual Property", Boston University Law Review, Volume 85.

Madary, Michael, 2014, "Intentionality and Virtual Objects: The Case of Qiu Chengwei's Dragon Sabre”, Springer: Ethics and Information Technology, Volume 16, Issue 3.

Meehan, Michael, 2006, "Virtual Property: Protecting Bits in Context", Richmond Journal of Law \& Technology, Vol. XIII, Issue 2.

Rumbles, Wayne, 2011, “Theft In The Digital: Can You Steal Virtual Property?", Canterbury Law Review, Volume. 17, Issue 2.

Usanti, Trisadini Prasastinah, January 2012, “Lahirnya Hak Kebendaan”, Perspektif, Volume XVII, Number 1.

Whitworth, Brian, November 2014, "Quantum Realism: The physical world as a virtual reality", Chapter 1, Massey University, New Zealand.

\section{Websites:}

Dragon Nest, https://sea.dragonnest.com/policy/operation-policy, accessed on $1^{\text {st }}$ March 2019.

Gravity.Inc. Ragnarok, indoragnarok, https://www.indoragnarok.com/tos/, accessed on $15^{\text {th }}$ February 2019.

Lazarus, David, 2010, A Real-World Battle Over Virtual-Property Rights, Los Angeles Times, http://articles.latimes.com/2010/apr/30/business/la-filazarus-20100430, accessed on $15^{\text {th }}$ Februari 2019.

$92 \quad$ Yustisia Volume 8 Number 1 (January-April 2019) $\quad$ The Concept Of Authorization ... 